\title{
長崎県北松地区における地すべり発生機構の特性
}

$$
\text { (平山地すべり一その } 1 \text { 一) }
$$

玉田文吾*

\section{Studies on the Mechanism of Landslide at Hokushō in Nagasaki Prefecture}

\section{by Bungo Tamada}

\section{1. まえがき}

地すべり発生の原因抢よびその機構については，上質 力学または地質構造の面からいろいろと吋議されている が, 複雑な自然要因に支配されることが多く, これら諸 要因上の相互関係が把握しがたいこと, 地中における地 すべり現象の進行を測定することに支障が多いこと，な どの理由によって決定的なものを見いだすととができて いない。

本報文は，長崎県北松浦郡吉井町平山地すべりに主体 を扔いて，その発生原因之機構の一端について及言した あのである。平山地すべりは，岩盤中に地すべり粘土を もつ層すべり面と岩盤と崩積土との層界面が地すべり面 になっている部分に分けることができるが，今般は前者 の場合について記述し，とくに次に述べる事項について 検討を加える。

いうまでもなく, 地すべり粘上の生成は岩石の風化現 象の結果とい执ているが，もし風化現象が普遍的なも のであれば，とのような地形と自然条件とをもつ所はど こでああり，どこであ地すべりが発生するはずである。 このことは，同一地すべり地内ですよく見受けられ，同 じ地質構造でありながら少し離れた場所では地すべり現
象が見られないよいったととをよく経験する。これに対 して，岩盤の傾斜が急であるとか，地すべり粘土ができ やすい層, または風化しやすい岩石で構成されていると いった説明をしている。すなわち, 必要条件ではある が，なぜ，その部分がすべるかいった充分条件を満た すためには，地中岩不の風化の機構になにかの特異性が あること，風化現象と地すべり粘土化との間になにか特 殊なメカニズムがあることなど説明する心要があると思 う。

一方, 地すべり粘土の力学的特性, とくに発生前後を 通じて重要な因子となるセン断強さについては，これら が地中に扎いて, 含水此とともにどのように变化してゅ くかの相互関係む必要である。

以上の事項を, 岩石の風化之粘土化過程については空 内実験走主体に考察し, 地すべり面の力学的性質につい ては地すべり初期に拈ける地表面の移動速度によって解 析したものである。

\section{2. 北松型地すべり}

長崎県北松浦郡沶よび佐世保市一带は「北松型地すべ り」といわれる地すべり多発地带であり, 平山地すべり などは写真に示すごとく（写真－1は地すべり発生時の

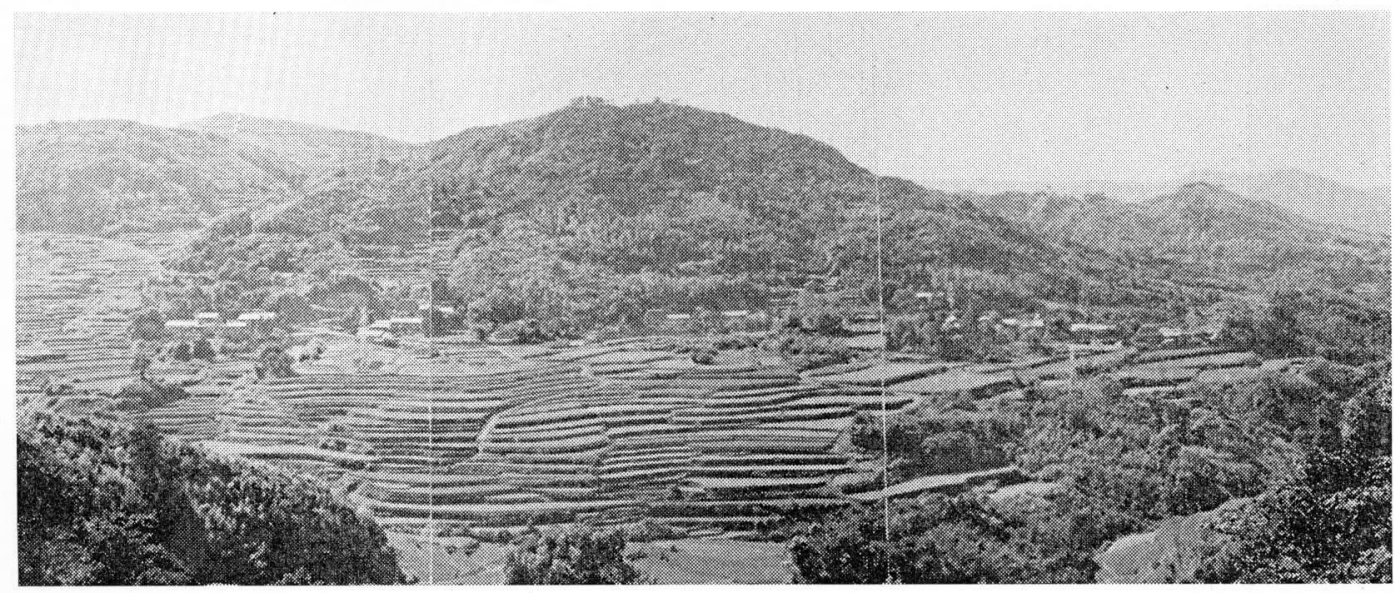

写真-1 長崎県北松浦郡吉井町平山地すべり発生時の全景（昭和38年10月，樽川内側より撮影）

* 九州工業高等学校 


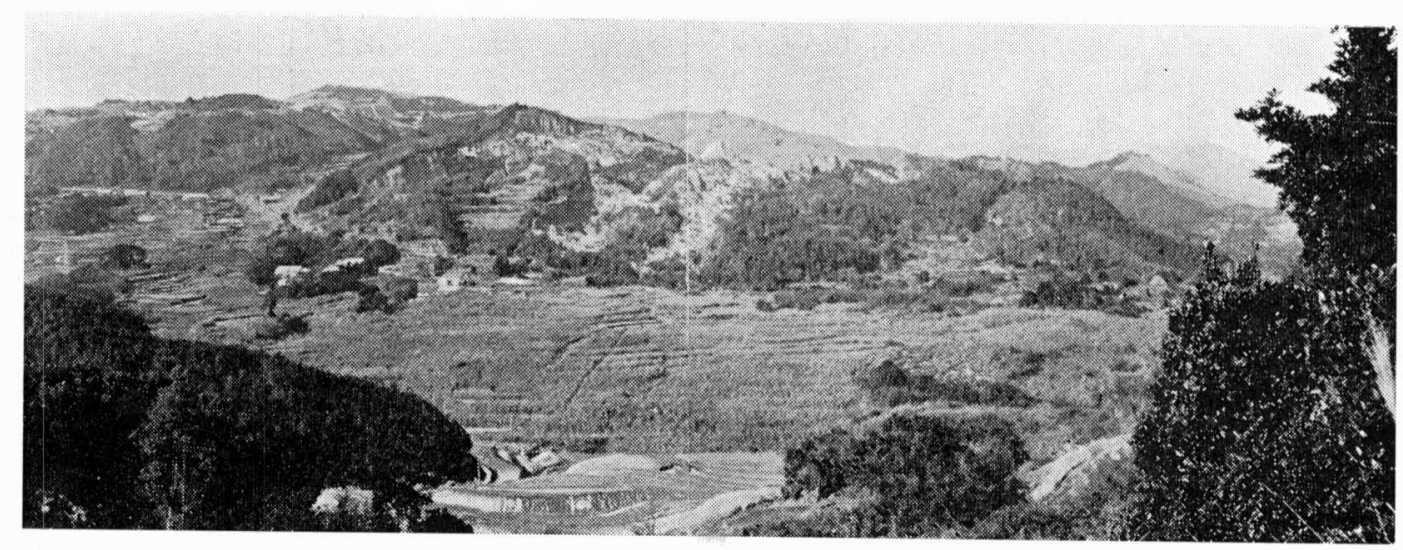

写真-2 平山地すべり崩壊後の状態（昭和 41 年樽川内側より撮影）

あの, 写真 -2 は地すべりが進行した昭和 41 年のむので ある。かなり大規模な地すべりを誘発している。北松地 すべりの範囲については, はっきりした定義はないが, 南北 $40 \mathrm{~km}$, 東西 $30 \mathrm{~km}$ の拡がりをむち，摤炭層である 佐世保層群の発達している地区で, 同時にかつては佐世 保炭田として40数余の稼行炭鉱があった所であある。現 在, 長崎県下の地すべりは大部分が北松地区に集中して いる感があるが，本報文の刘象となる長崎県県北開発振 興局林業部治山課管轄の10余の地すべり地区は，ほぼ地 区全域を散点的に求おい, 南部の佐世保市八尋を始め, 北松浦郡佐々町, 吉井町, 松浦市, さらに玄海灘に浮ふ 鷹島におよぶあのである。松浦市榎山地すべりの東側に は佐賀県伊万里市山代町と接する石倉山地すべり，人形 石山地すべり地区がある。

「北松型地すべり」の命名は, 九州大学野口教授によ るあのである11。これらの地すべりは第三紀層上に，こ れを不整合に被う厚さ $1 \sim 2 \mathrm{~m}$ ，あるいはそれ以上のレ キ層をへだてて厚い玄武岩の熔岩流が乗っており, 北松 一面を広く捄っって熔岩台地をつくっているが, その後 の浸食によって多くの谷をつくり, 玄武岩は一種の cap rock として残っている地区が多く, 柱状節理が発達し ていて雨水の浸透をたすける一方, てれらの崩壊を助長 して第三紀層上に玄武岩質疑灭角砂岩亡崩土をつくると 同時に, 基底部に溜った多量の水は粘土化した崩土の軟 化を促進して地すべりを誘発するあのであるとさ机てい る。

しかし，野田教授は長崎，佐賀県下の地すべり地区な いし兆候地では, 第三紀層中の頁岩, 石英粗面岩質疑灰 岩, 疑灰質頁岩がきわめてよく粘土化されていることに 注目すべきととを強調し, 地表面で見える現象の多くは 玄武岩や崩積層の滑落であるが, その根源は第三紀層中 にあると論じておられる。

(この種の地質構造に類似して地すべりを発生してい る地区に山口県大津郡油谷町に見られる「演谷地すべ り」がある2)。
事実，既述の地すべり地区の大部分（北松浦群小佐々 町大瀬, 田原の両地すべりは例外であるが, 田原地すべ りは cap rock が浸食によって消失したよいわれてい る。には玄武岩の cap rock が賦存しており, 玄武岩崩 積土内の地すべり面付近のいちじるしい粘土化が認めら れる。また, 第三紀層中の疑灭質頁岩, 頁岩の粘土化は 全部の地区に認めることができ, 平山地すべりでも疑灰 質砂岩が粘土化して現在の地すべり面の一部を形成して いる。このような地質構造地区に見られる地すべりを 「北松型地すべり」といっている。

\section{3.＼cjkstart地すべり発生と地表面の動き}

\section{1 移動とその意義}

地すべり現象は, 地表面の亀裂, 末端の盤膨机, 陥没 など,まず，われわれの感覚に捉えられて発見されるこ とが多い。とのような時期には地すべりはかなり進行し ているが, その後の地表面に求ける移動量は地すべりの 規模, 状態を知る目安として各地においてょく観測され ている。既述の地すべり地区において集水井，試錐孔を 利用した調査によれば，多くの場合が地すべり粘土を滑 剂とするあので，この上に乗っている土塊は単位ブロッ ク的な挙動をしているから，地すべり粘土層間の動きが 地表面の移動として近似的に表示されることむあり，地 すべり粘土の変形量が移動量に関係してくれば，あらか じめ地すべり粘土の物理性質, 応力と七ズミの関係など が判明していれば，移動量を観測することによって地す べり粘土の状態を推定するとともできる。

図-3.1は，ある石炭鉱山において天盤岩石が断層破哗 帯 (亀裂) A B C Dを滑動面として $\mathrm{B}_{2}$ 側のブロックが 自重で沈下する場合を模型的に表示したむのであるが， これは地すべり地域における層すべり挙動とよく似てい る。すなわち，AＢ在岩盤，A B C D 地すべり粘土， $\mathrm{C} D$ を崩䅡土などのブロックにたとえるととができる。 このとき $\mathrm{B}_{2}$ 面 (天盤岩石表面) の沈下量走測定したも のが図-3.2であるが, との場合, 破哗帯の状態によっ 


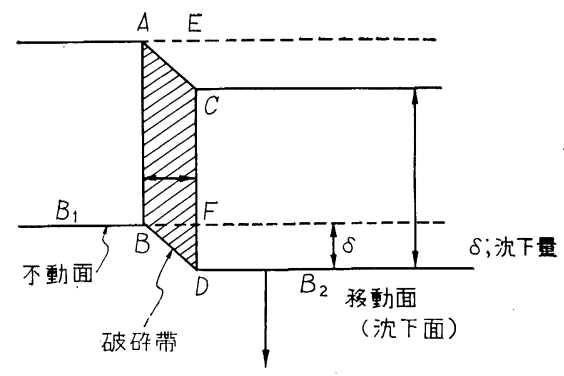

図-3.1 龟裂を含む天盤岩石沈下の模型表示

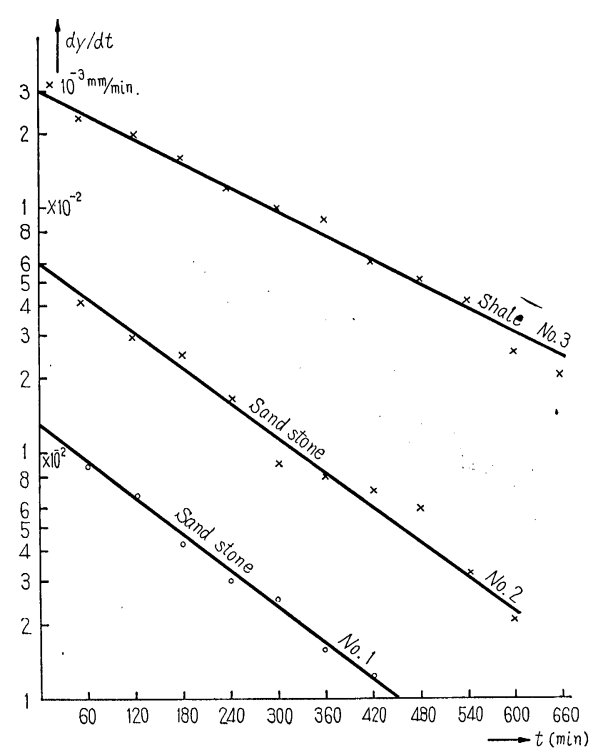

図-3.2 天盤岩石沈下速度の時間的変化

て沈下量に差違がある。しかし，同じ状態においては時 間変化の傾问は同様であるから，とのような盗料を集䄼 しておけば，すべり西面の状態がある程度推知できる。 地すべり移動量をこのような意味に使用するならば, 䅡分値としての移動量では不充分であり, 微分值として の移動量, すなわち少なくとも $\mathrm{mm} / \mathrm{day}$ 程度の速度と して，その㭙間们変化 $d x / d t-t$ として記録した方が刘比 上つごうがよい。

\section{2 移動速度と地すべりの分類}

地すべりの分類は，占来，多くの先学によって試みら れている。たとえば，移動の状態から分けたあのとして は継続的地すべりと間歇的地すべりに分類する方法, 移 動の様式によって阶弧型地すべり，平画型地すべり，䈻 行型地すべりに分ける方法，さらに流動（flow），滑落 (slip) に分けている问きむある。地すべりによって移動

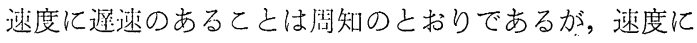
よる分類ができない大きな理田として，避速は概念的な

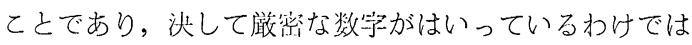
ないから，㐿者の区别むはなはだあいまいなむのになる

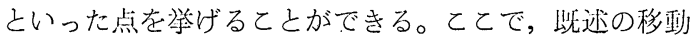

速度の洔渭们変化， $d x / d t-t$ 曲線の型によって地すべり を分類すると，層すべりの堤合などでは，地すべり粘土 または土塊の埒動を力学们相似型によって分類するとと になり，機棈を解析する場合にはつでうがよい。との見 地から地すべり移動速度の型を分けると次のようにな $3^{3)}$ 。

(1) V C 型地すべり

移耐速度が一定，すなわち $d x / d t=C$ の型で，平山地 すべり，北松浦郡吉井町梠川内地すべり，佐世保市柚木

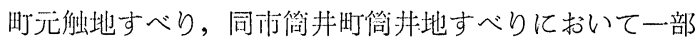
峴测されている。移動状沙加ら見て匍行型 (creep)とい う言葉がピッタリ合うような移動速度の時間的変化を示 †。

もちろん，乙の型の中でもCの数值にはかなりの差が あるが, $d x / d t-t$ 曲線の傾向としては同じである。詳し くは別に述べるが，乙の型は地すべり発生時または直後 には現われず，主として平陌的な層すべりの中期または 状期に現われやすい。地すべり粘土の力学啲性質と，乙 れに加わる応力とその状態が変化しない限りCの数值は ほぼ一定であり，地すべり粗上のレオロジー似性斦在解 く上に重要な意味をもつ型である。

(2) V F 型地すべり

移動速度が時閒経過と共に増加する型を呼称してい る。典型的なものは平山地すべりで推测されたが，地す ベり発生時，始端部に見られる $d x / d t-t$ 曲線であること から地すべり曲線 (landslide curve) と呼称した ${ }^{4)} 。$ 曲 線が湔落 (fall) 時の状態を良く示しているためにVF 型 というが，従来，移動速度が早いといった感じを表示す るために使用された landslide，landslip の型に該当する あのである。地すべり発生の原因を調查するためにぜひ 必要な資料になるが，此述のように地すべり現象が発見 されたときは琴㐾がかなり進行しているので完全なもの は得がたい。

\section{(3) V E 型地すべり}

$d x / d t-t$ 曲線が指数関数（exponential function）とな る場合で，佐怾保牧の地地すべり，北松浦郡小经々町 大瀬地すべりなどに見られる。との型を数式で表示する 之,

$$
\frac{d x}{d t}=A_{i} \cdot \exp \left( \pm B_{i} t\right)
$$

となるあのであり，図-3.2の形式となる。乙とに $A_{i}$ は 半対数方眼紙の縱軸に対数目盛の移動速度 $d x / d t$, 㭬軸 に算術目盛で経過時間 $t$ をとったとき $t=0$ に対応する 移理速度を表示したものであり，係数 $B_{i}$ は直線の勾配 である。

$$
B_{\imath}=\frac{\log A-\log x^{\prime}}{0.4342 t}
$$

この型の特徽としては，地すべり粘土を洞剤とする風 
表-3.1 角山地すべり地区に打ける移動速度曲線係数

\begin{tabular}{|c|c|c|c|c|c|c|}
\hline 测 点 係 数 & $A_{1}$ & $A_{2}$ & $A_{3}$ & $B_{1}$ & $B_{2}$ & $B_{3}$ \\
\hline $1-1$ & 0.82 & 89.50 & - & 0.0096 & 0.0532 & - \\
\hline $1-2$ & 1.78 & 3.50 & - & 0.0143 & 0.0198 & - \\
\hline $1-4$ & 1. 61 & 2.65 & 0.34 & 0.0194 & 0.0322 & 0.0058 \\
\hline $2-1$ & - & 0.75 & 0.31 & - & 0.0151 & 0.0063 \\
\hline $2-3$ & 0.97 & 11.00 & - & 0.0186 & 0.0342 & - \\
\hline $3-1$ & 0.96 & - & - & 0.0185 & - & - \\
\hline $3-2$ & 2. 05 & 5.05 & - & 0.0213 & 0.0260 & - \\
\hline $3-3$ & 1. 62 & 5.00 & - & 0.0299 & 0.0187 & - \\
\hline
\end{tabular}

表-3.2 天盤岩石の沈下曲線係数

\begin{tabular}{c|l|l}
\hline 測 点 & \multicolumn{1}{|c|}{$A$} & \multicolumn{1}{c}{ 係 } \\
\hline No. 1 & 0.0013 & 0.0057 \\
No. 2 & 0.0060 & 0.0057 \\
No. 3 & 0.03 & 0.0041 \\
\hline
\end{tabular}

( $A$ の临位は $\mathrm{mm} / \mathrm{min}, B$ の単位は $\min ^{-1}$ である)

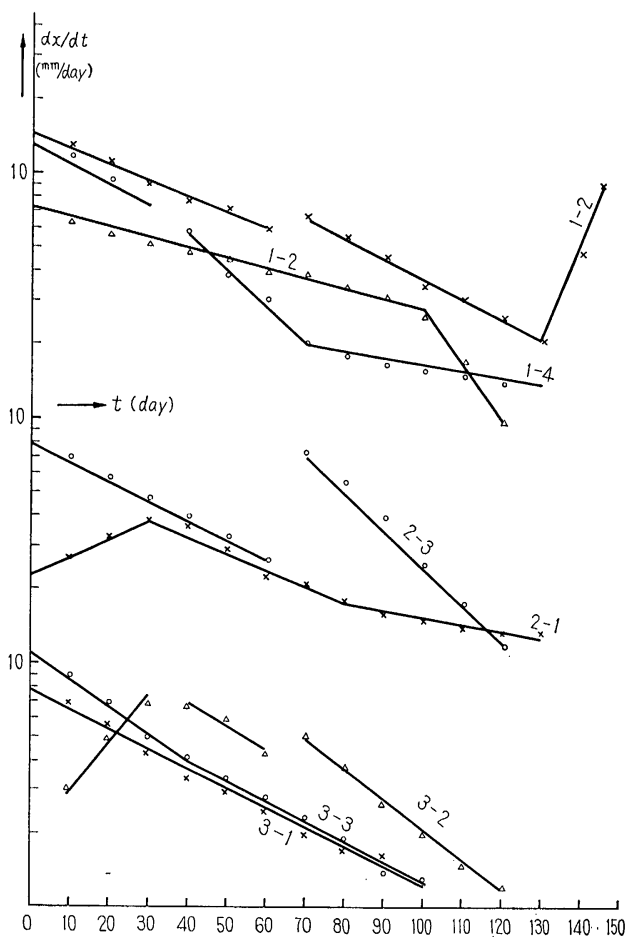

図-3.3 角山地すべり地区に括ける地表面移動速度の 時間的変化

すべりに見られるとと， $A_{i} ， B_{i}$ は時间経過と共に变化 するなどを挙げることができる。たとえば，山口県大㴋 郡油谷町所山地すべりでは図-3.3の $d x / d t-t$ 曲線が記録 され5)， $A_{i}, B_{i}$ の変化は表-3.1のようになっている。 表-3.2は図-3.2の曲線の係数を計算したものである。こ れら二つの図の傾向を比較すると単位の差はあるがかな り類似しているととは興味がある。鉱山の天盤岩不破础
州に見られるこのような挙動は，滑動值とこれをとりま く外部条件に起因する粘弾性的挙動であるととが判明し ているが，地すべりについても，ほぼ同じ考え方が適用 できるむのと思う。

(4) V Z 型地すべり

移動速度が時閌とは無関係に，不規則，不連続な挙動 をする埸合で，乙れを $d x / d t-t$ 曲線にするとジグザグな あのになる。とれについては別の機会にて述べるが，特 别な地尿条件のもとで発坐する型である。

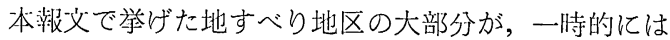
この型を示している。

\section{4. 平山地すべりの概要}

\section{1 平山地すべり地区の地質概要}

平山地すべりは，松浦線肥前吉料駅の献西約 $3 \mathrm{~km}$ 付 近にある槽高 $270 \mathrm{~m}$ の愛宿山の山腹斜面と山麓にかけて 起った地すべりで，被㲠面積は山林 17.5ha，水田29ha， 畑その他 13.5 ha におよぶ地すべり地である（被畫面科 は炤和 42 年頃)。その他，人家23戸の中の大部分の移転， 農耕不能, 県道高峰線の寸断, 高峰, 長谷川の土砂によ る堰き止めなどの被害が続発した。これに対して，地下 水の排除を含む種々対策が請じられているが，地すべり 機構はその大部分がその地区の地啠構造に偩うところが 多く，細部にわたっては，乙れが同一地区でむかならず しも同一でないとと，広筑囲な地域にわたって地中にお ける地すべり粘土の挙動または地下水流とその賦存状態 を把握することがむずかしいとと，地すべりを支配する 自然要因が複雑なととなどの理由によって，対策，処喵 に文障を来たしている面もある。

抯述のように平山地すべりは「北松型地すべり」の中 では規模が大きい方に属し，地すべり癷生時の状沿がよ く記録，钼察されているのでまず地竹概要から述べる。

この付近の基盤は符三紀中新址ないし渐新世に属する

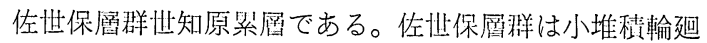
の繰返しと薄炭層の多いととがその特徵であるが6)，䄁 知原累層の下限には佐怗保炭田の稼行層である松浦三尺 
層があり，上位には砂盤層があるが，模式柱状による之 乙の間に下岩石, 一枚, 第一鱗状, 第二䚬状, 第三鱗状 の薄い炭層を摤んでいる。また, 佐世保層群中には凝灰 岩, 凝灭晌礫岩, 凝灭質頁岩, 浮石質砂岩を堆樍輪廻末 期頃に含んでいる7。

本，平山地区の基盤中にも松浦三尺層と砂盤層との間 には溥い炭層があって（松浦三尺層の上位倒に $90 \mathrm{~m}$ ，砂 盤層の下位侧へ $60 \mathrm{~m}$ ）厚さ数センチメートル内外の 2 3 枚の炭層が白色の凝灰質細粒砂岩中にはさまれてい る。との地質構造が後述するように地すべりに重要な役 目を果たしている。佐址保層群の一般的な特徵として砂 岩が多いととが挙げられるが，本地区の基盤も優砂岩の 層で構成されている。乙の壮知原糸層の上位には第四紀 洪積層といわれる「八の久保砂礫層」があり，てれらの 上を松浦玄武岩の熔岩流が覆っている。これは黒色繳密 な無斑晶玄武岩で平山地区のものは佐世保層群とてれら を覆う符四紀堆樍層を被覆する最下位のものといわれて いる。平地地すべり地区の滑動後の地質断面図を模式的 に示すと図-4.1のようになる。

平山地区の地形は侵食作用によるもので，西側と東侧 は侵食谷である長谷川之高峰川があり, 凝灰質砂岩およ びこれらにはさまれた石炭層の露頭線を見ることができ る。露頭線から低標留の部分には凝灭質砂岩は見られ ず，後で述べるような崩積土が㠜灰質砂岩の下位にある 砂岩を直接に被覆しているが washoutによるあのと思え る。

一方, 松浦玄武岩も風化侵食を受けて，愛宕山山頂付 近に caprock 状として残っているほかは, 玄武岩の咸 積土として山腹, 山麓面を広く㙏っている。玄武岩の caprock は柱状節理がきわめてよく発達して雨水の浸透 面となると同時に地下水の流路ともなっている。また， 図-4.2の平面図(初期の状態を示した昭和40年頃のもの)

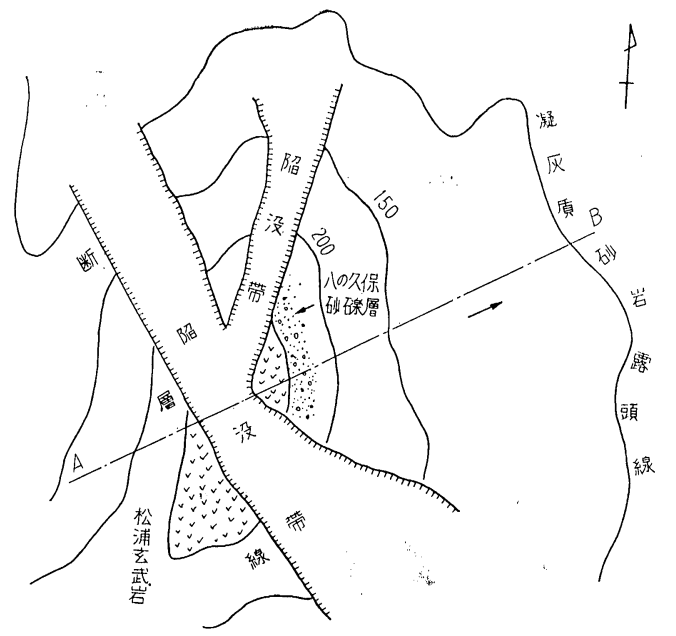

図-4.2 平山地すべり発生後の平面概略図

に示したように地すべり地区の南側には NW-SE の断 層破硉湍が走っている。

\section{2 地すべり発生時の状態}

平山地すべりは, 発生する約 3 年前からその徵候らし い現象が見られた。

(1) 骝和 35 年11月頃から愛宕山山麓にあった井戸水の 枯渴, 水田利用の淿水の減少などの徵候があり, 翌36年 6 月には現在の舌端と山簏を結ぶ線上に龟裂が発生して 末端にある水田の一部は隆起現象を起こした。

(2) 昭和 37 年 7 月集中豪雨によって高峰川, 長谷川河 岸段丘の一部が崩壊現像を伴う地すべり（小規模な）を 誘発した。

（3）昭和38年 9 月26日山頂部に亀裂のあるととが発見 され調查の結果, 慗高250 270mの地点に北東加南西 にのびる幅 $80 \mathrm{~m}$, 落差 $0.2 \sim 1.5 \mathrm{~m}$ 亿㧍よふ 2 本の平行亀

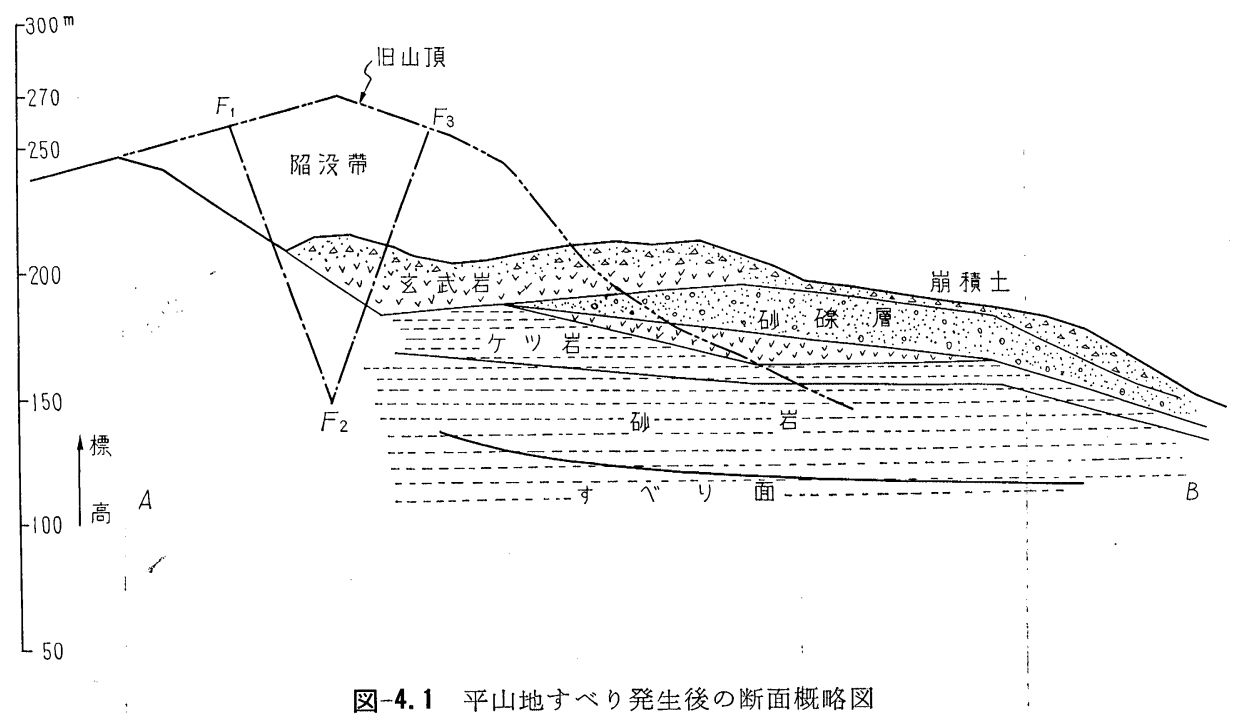


裂が見岕された。むち万ん，てれらの鼠裂は，可態がか なり進行してから発見さ机たものであり, 発生日時につ いては不明である。

（4）この 2 本の平行龟裂阔の地垉はその後陷没を始め て，遂には写其の如く愛宕山の $1 / 3$ を残し，2/3が移動す る端綃となった山頂楔形の原形である。

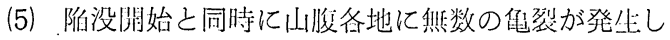

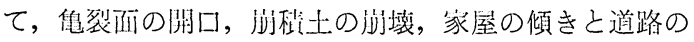
陷没, 未端付近の隆起と泭壞が顕著となった。

\section{3 陥没地付近の状態}

地表面に龟裂を発見した後，各地に伸綃計，傾斜部を

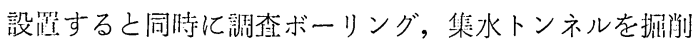
した結果，おむな地すべり阿は咋述の薄い炭層をはさむ 凝灭斦砂岩であり，乙の㠜成斦砂岩が washoutされてい る部分は，第三紀層の基盤と崩䅡土との間にすべり面が あるととがわかったが，砂岩層の上位にある頁岩または 崩積土内部にも地すべり面を見いだすととができた。総 体的には地すべり面は連続的な平面ではないととが明ら かにされたが，乙れは重要な瞔項である。また，陷没部 分のある断面は図-4.1のように $\mathrm{F}_{1} \mathrm{~F}_{2} \mathrm{~F}_{3}$ のような梛をな していることが判明した。背部 $\mathrm{F}_{1} \mathrm{~F}_{2}$ の一部は断層面で あることはすでに述べたが， $\mathrm{F}_{2} \mathrm{~F}_{3}$ 西の生成について心 二つの理的が考えられる。

1. $\mathrm{F}_{1} \mathrm{~F}_{2}, \mathrm{~F}_{2} \mathrm{~F}_{3}$ 西方水平面之なす倠度は約 $70^{\circ}$ とな

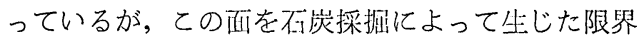
们面之見なす埸合。

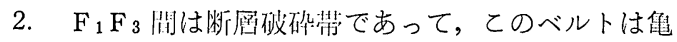
裂が発達した部分であると考える場合。

伯没部分は試錐による調查では多数の龟裂によって分 制されたブロック状を呈しているが，三湖形の頂点をな
す部分，すな打ち $\mathrm{F}_{2}$ 点以深には觬裂はなく，集水トン ネルによってもとれ以樑の層はほとんど政いていないて とが加かった。ただ $\mathrm{F}_{2}$ 付近には泥上化した㠜灭犋砂岩 があり，ての付近まで地下水は倵存していない。

龟裂の発生原因については陌没曲線の項で検 詩する が，平山地すべりはこの $\mathrm{F}_{1} \mathrm{~F}_{2} \mathrm{~F}$ 3 部の伯没開始と共に大 きな地すべり現㿝が見られている。したがって，てれら の相互関係については， $\mathrm{F}_{1} \mathrm{~F}_{2} \mathrm{~F}_{3}$ 部が䧃没したために前 而の山体を押し山し，て机が直揬原园となってすべりを 大きくしたものであるか，凝欧斦砂㞸付近をすべり而之 して移動したために㫟没を発企したものか微妙な問題が 残されている。しかし，結喿啲には陷没部分は地すべり 始発部付近になり， $\mathrm{F}_{1} \mathrm{~F}_{2}$ 而を滑落崖とする円弧すべり と層すべりとの複合の状態を星している。

\section{5. 地層面の吸水崩罣現象}

\section{1 岩石の風化現象}

既述のように，平山地すべり地区においては，地層中 のある百化㧊いて地すべり粘上層といわれる軟弱な地層 を見州すととができる。このようなすべり阬ができると とによって発少:する地すべり琴稂は，地形之粗上層の物 理力学的性斦の差非によって既述の移政形態を示すが, このような地すべり粘土は一般の場合，ある層中への水 の浸透とこれに伴う地層の哨壊現象（風化および地すべ り粘土化現承）の結果监成するといわれている。地す心 り発生後，地すべり粘上となった同一層で未だ地すべり 粘土化していないものについて物理力学的性所を比较す ると，含水比，閩ゲキ比などにいちじるしい差僬が見ら れる。しかし，てのような自然現嗮が地中においてどの ような過程をたどって進行するかについては判然としな

表-5.1 地すべり粘土と風化岩石の工学的性質

\begin{tabular}{|c|c|c|c|c|c|}
\hline 工学的性斦 & $\begin{array}{l}\text { 平 } \\
\text { 地すべり粘土 }\end{array}$ & 元触風化真岩 & $\begin{array}{l}\text { 元 熘 } \\
\text { 地すべり粘土 }\end{array}$ & 伯化粘性土 & $\begin{array}{l}\text { 僬す地べり粘土 } \\
\text { 地す }\end{array}$ \\
\hline 土粒子比重 & 2. 642 & 2. 663 & 2. 621 & 2.780 & 2. 761 \\
\hline 湿澗密度 $\left(\mathrm{g} / \mathrm{cm}^{3}\right)$ & 1. 669 & 2. 214 & 1.825 & 2.076 & 1. 861 \\
\hline 含 水 比 $(\%)$ & 45.2 & 8.98 & 33.6 & 19. 1 & 27.6 \\
\hline 乾焒密度 $\left(\mathrm{g} / \mathrm{cm}^{3}\right)$ & 1.149 & 2.032 & 1. 366 & 1. 731 & 1. 458 \\
\hline 間ゲキ此 & 1. 299 & 0.311 & 0.919 & 0.606 & 0.893 \\
\hline 飽 和 度 $(\%)$ & 91.8 & 76.8 & 95.8 & 91.3 & 85.3 \\
\hline 液性限界（\%) & 63.6 & & 55.5 & 45.9 & 55.4 \\
\hline 塑性限界（\%) & 24.3 & & 18.5 & 21.6 & 26.7 \\
\hline 塑性指数 (\%) & 39.3 & & 37.0 & 24.3 & 28.7 \\
\hline 流動 指 数 & 5.8 & & 13.5 & 11.0 & 11.8 \\
\hline 砂 分 $(\%)$ & 37.8 & & 3.5 & 3. 0 & 3.5 \\
\hline シルト分 $(\%)$ & 40.4 & & 66.5 & 56.5 & 55.5 \\
\hline 粘土分 $(\%)$ & 21.8 & & 30.0 & 40.5 & 41.0 \\
\hline 粘浮 力 $\left(\mathrm{kg} / \mathrm{cm}^{2}\right)$ & 0.26 & 4.67 & 0.23 & 0.88 & 0.14 \\
\hline 内部摩摖佰（deg） & $35^{\circ} 00^{\prime}$ & & $20^{\circ} 10^{\prime}$ & $30^{\circ} 00^{\prime}$ & $26^{\circ} 15^{\prime}$ \\
\hline
\end{tabular}


表-5.2 堆積岩の大気中に批りる強度低下

\begin{tabular}{l|l|l|l|l|l|l|l}
\hline \hline 経過㭙間(day) & 0 & 10 & 20 & 30 & 40 & 50 & 60 \\
\hline 压縮強度 $\left(\mathrm{kg} / \mathrm{cm}^{2}\right)$ & 48 & 28 & 20 & 16 & 10 & 10 & 9 \\
\hline
\end{tabular}

温度 $19 \sim 25^{\circ} \mathrm{C}$, 湿度 $90 \sim 95$ その大気中（鉱山坑道）

い点が多い。

表-5. 1飞平山地すべり，元触地すべり，諙山地すべり について地すべり粘土化する前の岩石（かなり風化して 粘性土に近いむの）の工学的性買と, 地すべり粘土化し た同一岩石の工学的性澌を比較したものを揭げた。平山 地すべり地区のむのは既述の凝灰質砂岩, 元触地すべり 地区のものは佐世保層群世知原層上部を不整合に被㠅す る松浦立武岩層中にはさまれる $\left(\mathrm{B}_{1}\right.$ 層と $\mathrm{B}_{2}$ 層との間)頁 岩層, 偷山地すべり地区のものは油谷滦層群的山糸層の 頁岩層である。表-5.1を見ると, 現在地すべり粘土とな っているあのについては, 含水比, 間ゲキ比, 飽和度の 増加が顕著であるが，これらのととは地層面の地中にお ける吸水膨張崩壊現象が加わった地すべり粘土化であ る。地すべり地区においてよく見受ける現象の一つとし て同一層においてもある部分だけが移動して，隣接した 部分には異常がないととがあり, 一方, 特殊な地形に地 すべりが多く見られることなどから考え合わせると，い かなる自然条件のもとに粘土化が進行するかについて検 討する必要がある。

堆積岩（とくに第三紀層以降のあの）は水の直接, 間 接的な作用によって漸次強度を減少してゆくが，てれを 岩盤の風化による強度低下といっている。表-5. 2 は頁岩 の高湿大気中における圧縮強度の時間的変化を示したも のであるが, 一般には強度の低下率は岩石の種類, 岩石 を構成する鉱物粒子の固結物梊と程度によってかなり異 なっている。ここで, 地下水による強度低下と崩壊過程 を調べるために, 平山地すべり地区, 元触地すべり地区 の凝灰質砂岩之頁岩について, 地すべり粘土之同一岩層 で，かつ，これに接近し地すべり粘士になっていない部 分のボーリングコアおよび集水トンネル内から得られた 岩塊を直径 $5.5 \sim 5.6 \mathrm{~cm}$, 高さ $2.0 \mathrm{~cm}$ 前後に整殁したテ
ストピースをつくり，静水中に水浸して時間経過ごとに これの直控セン断試験（一面セン断試験機使用）走行な ったものが図-5.1であり, 図の左上侧にセン断強度 $S$ と 會水比 $w_{s}$ との関係を示した。こ机によると両者の間に は $w_{s}$ がある筑围において近似的に

$$
S=S_{0} \exp \left(-n w_{s}\right)
$$

の関係がある。ここで式 (5.1) の記号は

$S_{0}$; 半対数方眼紙において $w_{s}=0$ と直線と 交点との数值

$n$; 直線が $w_{s}$ 軸となす勾配に関する係数 を表わす。

したがって，含水比 $w_{s}$ が増师すれば，セン断強度は 急速に低下してゆくことになる。一方，水漫テストピー スの水浸経過時間 $t$ 亿対するセン断強度 $S$ の変化につい

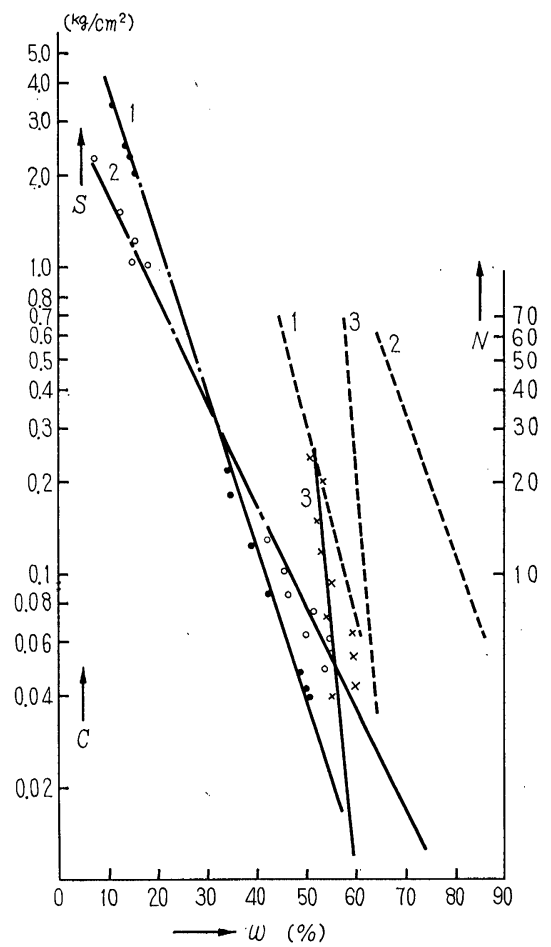

図-5.1 セン断強度，粘着力と含水比の関係

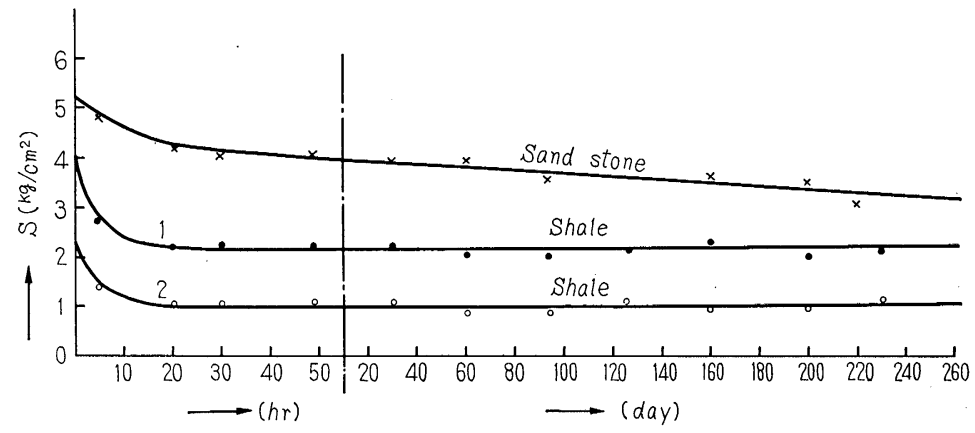

図-5.2 水浸風化岩石の強度変化 
表-5.3 風化岩石の水浸テストによって起こる強度低下係数

\begin{tabular}{|c|c|c|c|c|c|c|c|}
\hline 系石種類 & 数 & $S_{0}$ & $n$ & $S_{a}$ & $\beta$ & $\gamma$ & 採 取 地 区 \\
\hline 1 頁 & 岩 & 11. 20 & 0.116 & 4. 67 & 0.77 & 0.236 & \multirow{2}{*}{$\begin{array}{l}\text { 佐断保帊柚水町元你 } \\
\text { 長崎県北松浦郡吉井町 }\end{array}$} \\
\hline 2 頁 & 岩 & 3. 75 & 0.079 & 2. 58 & 0.88 & 0.192 & \\
\hline
\end{tabular}

ては，図-5.2のようになり，テストピースのあるむのに ついては,だいたい

$$
S=S_{a} e^{-\beta\left(1-e^{r t}\right)}
$$

で表示され，時閂経過とともに一定值に近づくが，式 （5.2）の定数，係数については，乙れを表-5.3にまとめ た。矢験の結果を若察すると，岩不の吸水萠壊現邹につ いて次の柔項が考えられる。

（1）採取したままの試料（気乾を許さぬようにして） を一定量の水に水浸した場合, セン断強度は水浸後急激 に低下するが，ある程度まで低下すると，それ以降水中 で静止状態におかれた試料の強度はほとんど低下しな い岩石がある。堆積岩の鉱物粒子を固結している物犋 (Cementing material) は，炭酸不灰，珪酸，酸化鉄な どであり，風化現象とはこれら固結物質の水中への溶 壵，分解を伴う化学的作用之，鉱物粒子間膠結物の機械 的な破砕作用を主体とする物理的風化作用であり，水中 に怙ける強度低下は前者の化学的風化作用之推定され る。すなわち, 最初の段階では溶解しやすい嫶類—K, $\mathrm{Na}, \mathrm{Ca}, \mathrm{Mg}$ などの硫酸塩，炭酸塩などが溶出し，珪酸 $\left(\mathrm{SiO}_{2}\right)$ むアルカリ水溶液中では溶解する。ついで鉄な どが不努定な $\mathrm{Fe}\left(\mathrm{HCO}_{3}\right)_{2}$ をつくり, $\mathrm{Fe}^{2+}$ イオンとして 溶液中に存在するようになる。そこで腃水中における堆 䅡岩固結物質の可溶量を測定するため試料 $100 \mathrm{~g}$ を表面

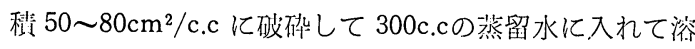
解度を調べたものが図-5.3である。これによると $\mathrm{Ca}^{2+}$, $\mathrm{Mg}^{2+}, \mathrm{HCO}_{3}{ }^{-}, \mathrm{Fe}^{2+}, \mathrm{SO}_{4}{ }^{2+}$ イオンは水漫後30日前後 から一定濃度となり，乙の結果と先に述べた強度低下の 割合を比較すると，一定量の静水中では化学的風化の進 行しがたいととが強度低下に影響しているように思え る。平山地区の水質分析結果は表-5.4のようである。

実験に使用した平山，元触地区の岩石では，長時間に わたっての強度低下割命の時䦌的変化は, 頁岩が最も小 さく, ついで砂岩, 砂質頁岩の順序となっている。もち ろん，式 (5.2) に示される係数は岩石によってかなりの 差違があること，いいかえると㞸不の水に対する風化抵 扰にはいちじるしい違いがあるというととを示してい る。

（2）佐世保層群には小堆皘輪迴の繰返しが見られ，乙 れら小輪迴中には火成活動に起因する凝灭岩, 凝灰觕磁 岩, 凝灭啠頁岩, 凝灰翼 (浮石質) 砂岩などの凝灰質の 堆稆闃が見られる。これらの岩不を水浸すると強度低下 が大きく長時闃においてセン断強度はかなり小さくなる

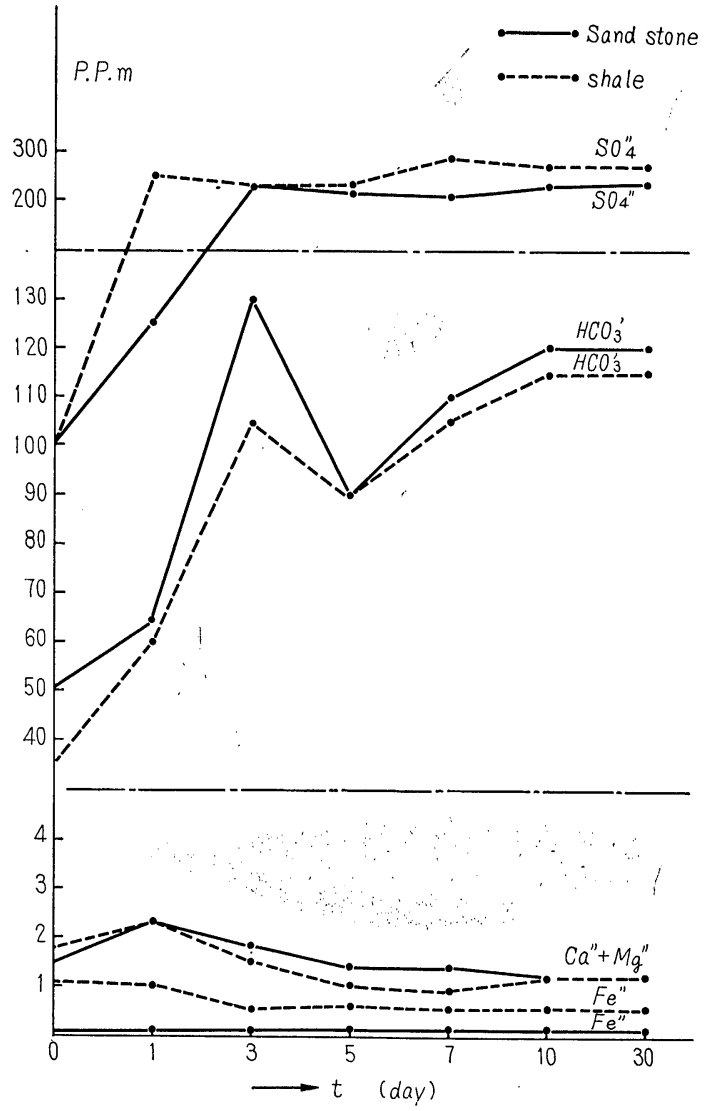

図-5.3 岩石の溶解曲線

が，静水中では自己崩壊するととはない。

（3）水浸した試料が水中において自己崩壊するのは, 次のような岩石に多い。

1）試料を空気乾燥すると岩種にあまり関係なく，短 時閒に表面から崩壊して水中に流れ岕す。との崩壊 までの時間は, 岩種, 乾燥状態によって差筷がある が，これらの相互関係については琴不のところはっ きりわかっていない。てれに類似の現缘は野外に放 阷したボーリングコアの降雨などによる自己崩袬に よく見られる。

2) 北松地区には二次的堆積岩が多く見られる。二次 的堆積岩とは第三紀の砂岩, 頁岩, ときには風化し た玄武岩が崩壊して崖錐性の堆秘（萠積）層となっ ている場命で，岩相は破砕した母岩岩扸が不規則な 粒度構成をしている固結度の低い状態を呈してい る。こ机らを水浸すると岩片に分離して水中におけ 
表-5.4 平山地すべり地区湧水の水質分析

\begin{tabular}{|c|c|c|c|c|c|c|c|c|c|c|c|}
\hline 誹定 & $\begin{array}{c}\text { 気 } \\
\left({ }^{\circ} \mathrm{C}\right)^{\text {温 }} \\
\end{array}$ & $\begin{array}{l}\text { 水 }{ }^{\circ} \mathrm{C} \text { 温 } \\
\end{array}$ & $\mathrm{pH}$ & $\begin{array}{c}\text { 雷導度 } \\
(\mathrm{ohm} / \mathrm{m})\end{array}$ & $\begin{array}{l}\mathrm{HCO}_{3}^{-} \\
\text {(P.P.M) }\end{array}$ & $\begin{array}{c}\mathrm{Ca}^{2+} \\
(\mathrm{P} . \mathrm{P} . \mathrm{M})\end{array}$ & $\begin{array}{c}\mathrm{Mg}^{2+} \\
(\mathrm{P} . \mathrm{P} . \mathrm{M})\end{array}$ & $\begin{array}{c}\mathrm{Cl}^{2-} \\
\text { (P.P.M) }\end{array}$ & $\begin{array}{c}\mathrm{SO}_{4}^{2-} \\
(\mathrm{P} . \mathrm{P} . \mathrm{M})\end{array}$ & $\begin{array}{c}\mathrm{SiO}_{2} \\
\text { (P.P.M) }\end{array}$ & 備 \\
\hline 0 & 16.0 & 15.8 & 6.8 & 690 & 249.5 & 103.1 & 49.7 & 6.4 & 226.0 & 35.7 & 高峰炭 鉱内水 \\
\hline 1 & 14.8 & 12.0 & 6.5 & 340 & 93.7 & 47.1 & 22.7 & 7.1 & 120.0 & 31.3 & 長谷川川川河水 \\
\hline 2 & 14.8 & 15.8 & 6.6 & 660 & 323.3 & 112.6 & 31.8 & 10.0 & 158.0 & 45.1 & Boring. $\mathrm{B}-2$ \\
\hline 3 & 15.8 & 15.0 & 6.3 & 820 & 296.6 & 142.0 & 46.6 & 7.0 & 298.0 & 43.0 & 集水トンネル湧水 \\
\hline 4 & 16.0 & 15.7 & 7.0 & 1,200 & 304.5 & 229.5 & 68.4 & 6.4 & 548.0 & 38.8 & 地すべり末端の崩䅡土中 \\
\hline 5 & 16.8 & 15.5 & 6.7 & 740 & 358.4 & 125.1 & 498.7 & 10.1 & 177.5 & 37.8 & $"$ \\
\hline 6 & 17.0 & 15.8 & 6.8 & 820 & 404.4 & 135.1 & 568.1 & 8.2 & 202.5 & 39.5 & $"$ \\
\hline 7 & 17.0 & 13.5 & 5.6 & 290 & 3.2 & 8.2 & 9.5 & 46.0 & 1.0 & 21.6 & $"$ \\
\hline 8 & 16.0 & 12.0 & 6.3 & 78 & 7.0 & 3.9 & 2.6 & 12.5 & 2.0 & 15.5 & " \\
\hline 9 & 15.5 & 13.7 & 6.6 & 52 & 5.9 & 1.8 & 1.7 & 8.2 & 1.6 & 20.9 & $\mathrm{GL}-3.60 \mathrm{~m}$ \\
\hline 10 & 18.5 & 12.5 & 6.4 & 310 & 27.2 & 39.7 & 13.0 & 60.0 & 45.9 & 84.0 & 北戸水(使用せず) \\
\hline 11 & 15.8 & 11.0 & 6.0 & 75 & 6.4 & 3.6 & 2.6 & 16.5 & 0.9 & 27.3 & 地すべり末端の崩临土中 \\
\hline 12 & 15.0 & 14.5 & 6.3 & 90 & 41.6 & 7.1 & 2.8 & 8.0 & 0.8 & 67.2 & Boring. $\quad 0-1$ \\
\hline 13 & 16.5 & 14.0 & 6.6 & 82 & 32.0 & 6.5 & 2.9 & 9.3 & 0.9 & 44.0 & 水 \\
\hline
\end{tabular}

表-5.5 吸水膨張試験に使用した 地すべり粘土の物理性質

\begin{tabular}{ccccc|r}
\hline \hline 土 & 粒 & 子 & 比 & 重 & 2.62 \\
液 & 性 & 限 & 界 & 51.5 \\
塑 & 性 & 限 & 界 & 34.7 \\
塑 & 性 & 指 & 数 & 16.8 \\
流 & 動 & & 指 & 数 & 9.5 \\
レ & & キ & & 分 & 2.0 \\
砂 & & & 分 & 21.9 \\
シ & \multirow{2}{*}{ ル } & & 分 & 56.1 \\
粘 & & 土 & & 分 & 20.0 \\
\hline
\end{tabular}

る砂䃯のような状態になる。

\section{2 粘性土の吸水膨張}

岩石の水漫テストの結果, 含水比の增加にともなって セン断強度が低下することは式 (5.1) に示したとおりで あるが，含水比の増加とは岩石の吸水であり，乙の現象 は間ゲキ比の增加すなわち吸水膨張になってくる。強度 低下については先の垁験によってその経過を推定するて とができたが，乙のときの吸水膨張については傾向を知 るととがむずかしいとと，水浸岩石は吸水膨張を続けて 粘性土，さらには地すべり粘土へと進行しなければなら ないが，後述するようにこの過程は静水中では再現でき ないので, この間の状態を知るために, 表-5.5に示した 物理的性貿をむつ地すべり粘土付近の粘性土によって, 現地の状態に近いテストピットなどをつくり, 図-5.4の 装置を使用して吸水膨张試験を行なった。

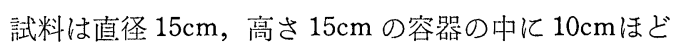
単位体積重量および含水比をそれぞれ変えたものを詰め ている。一方, 容器の底板は不透水性の金属板で水の通 過を防止したが，その理由は平山地すべり地区における 地すべり粘土層の下部には不透水性の岩盤があることを 想定したものである。試料に対する給水は上部多孔板を 通して行なったが，一般に地層に対する地下水の浸透は 地中龟裂を通じて一方から補給されるととが多いのでと れを模型化した。さらに，地中のある層面は土かぶり応

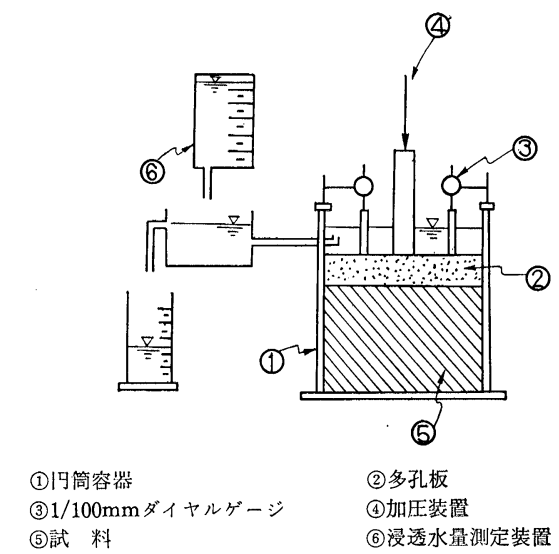

図-5.4 吸水膨張試験装置

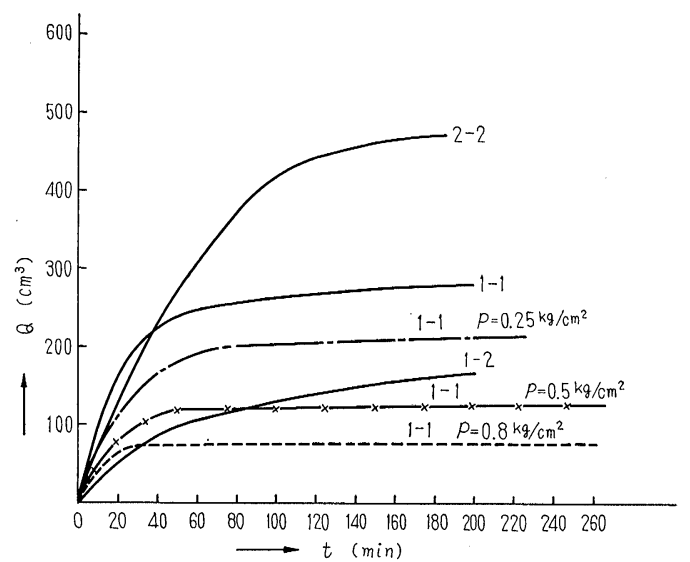

図-5.5 浸透水量の時間変化

力（地圧）を受けるので，乙れに相当する応力を与える ため加圧装置をとりつけた。すちろん，乙の装置と地層 の吸水膨張とはかなりの差があると思えるので，得られ た数値の解釈には問題が残されていると思う。

ここで試料に漫透する水量を $Q$ ，給水時間を $t$ とす れば，乙の間の関係は図-5.5の実線に示すようになり， $Q$ と $t$ との間には近似的に次の実験式が見いだされる。 


$$
\begin{aligned}
& Q=Q_{s 1}\left[1-e-K_{1}\left(t-t_{0}\right)\right]+Q_{s 2}\left[1-e^{-K_{2}\left(t_{2}-t_{1}\right)}\right] \\
& \text { 十- - } \\
& \because \quad Q_{s i}=Q_{a \imath}-Q_{c i}, K_{2}>K_{2}>\cdot \cdot \cdot \\
& Q_{\mathrm{s} 1}>Q_{\mathrm{s} 2} \cdot \cdots
\end{aligned}
$$

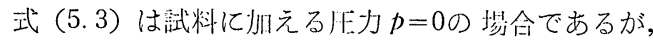
吅止装踏にって $p>0$ にしてゆくと $Q$ は

$$
Q=\left(Q_{a}-Q_{c}\right)[1-\exp (-K t)]
$$

の形式に移行するようである。

ここに $Q_{a}$; 試料の吸水膨張が完了したときの試 料中の含水星 $\left(\mathrm{cm}^{3}\right)$

$Q_{c} ;$; 试験前侙料に含まれている含水昷

$K$; 试料の物理的性所, とくに透水係数 に関係するもので，門䢹に刘灾する 係数である。

この場合, 浸透水量 $Q$, 経過時闰 $t$, 压力 $p$ との閑 には図-5.5の破線で表わした関係，すなわち式 (5.4) と なるが， $Q$ と $p$ との閏には，同一の試料において

$$
Q=Q_{0} \exp (-s p)
$$

の関係がある。

ここに

$Q_{0}$; 侙料に压力を加えないときの吸水膨 张㭙の念水量 $\left(\mathrm{cm}^{3}\right)$

（式 (5.5) の関係を半刘数与腿紙に プロットしたとき, 縱軸 $p=0$ と直 線の交点との数值)

$p$; 試料に加える圧力 $\left(\mathrm{kg} / \mathrm{cm}^{2}\right)$

$s$; 試料に加える王力 $p$ に関する係数で 試料の䦌ゲキ比 $e-p$ 曲線に関係す る。

一般に地中における地層は，空洞がなければ $p=r_{s} ・ h$ （ $r_{s}$ は地中岩石の単位体積重量， $h$ は深度）を受けるはず であり，普通の場合には $p$ 然関係ということはない。

したがって，てのような粘性土層が地層中にはさまっ

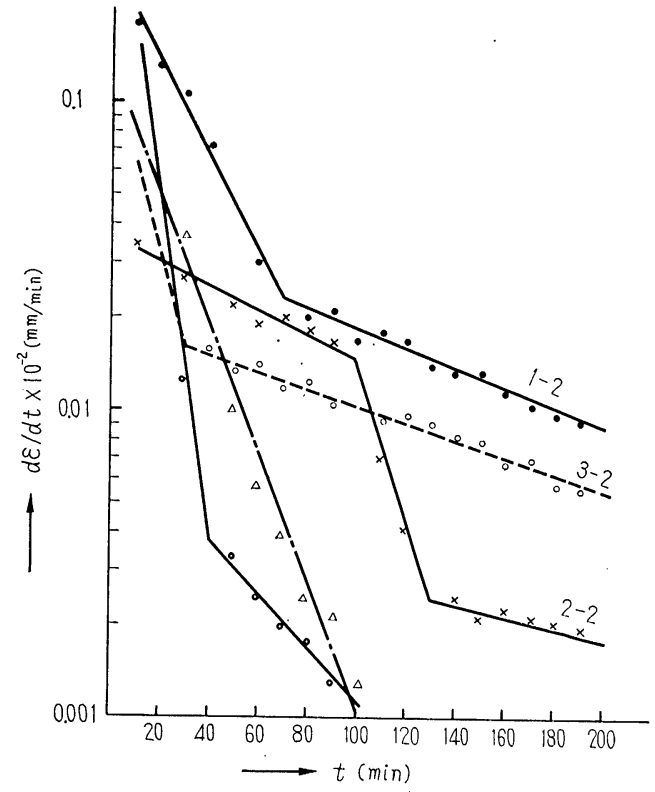

図-5.6 吸水膨張率の時間的变化

ているとすれば，深度 $h_{a}$ に対応する $p_{a}$ を受けるととに なるから，試料と同じ吸水膨張条件にあるものとすれ ば，乙れが耗などを通じて給水されるときの浸质水是 $Q$ は

$$
Q=\left[Q_{0} \exp \left(-s p_{a}\right)-Q_{c}\right][1-\exp (-K t)]
$$

である。 $p$ によって浸透水量 $Q$ が変化する理由は, 透 水係数 $k$, 間ゲキ比 $e$ に関係するあので, 試料に加える 圧力が $k, e$ 亿影響を与え浸透水量が变化するものと䍐

\begin{tabular}{|c|c|c|c|c|c|c|c|c|c|c|}
\hline $\begin{array}{l}\text { 試験 } \\
\text { 番号 }\end{array}$ & 含水比 & $\begin{array}{c}\text { 乾燥密度 } \\
\left(\mathrm{g} / \mathrm{cm}^{3}\right)\end{array}$ & $\begin{array}{l}\text { 初 期 } \\
\text { 問ゲキ比 }\end{array}$ & $\begin{array}{c}\text { 飽和度 } \\
(\%)\end{array}$ & $\begin{array}{l}\text { 吸水後 } \\
\text { 含水比 }\end{array}$ & $\begin{array}{l}\text { 吸水 後 } \\
\text { 閆ゲキ比 }\end{array}$ & $\begin{array}{c}\text { 吸 水 後 } \\
\text { 飽 和 度 } \\
(\%)\end{array}$ & $\begin{array}{c}\text { 膨張率 } \\
(\%)\end{array}$ & $\begin{array}{l}\text { 吸 水 後 } \\
\text { 乾燥密度 } \\
\left(\mathrm{g} / \mathrm{cm}^{3}\right)\end{array}$ & $\begin{array}{c}\text { 吸 水 聂 } \\
\left(\mathrm{cm}^{3}\right)\end{array}$ \\
\hline 1 & 57.4 & $\begin{array}{l}0.864 \\
0.915 \\
0.997\end{array}$ & $\begin{array}{l}\text { 2. } 032 \\
\text { 1. } 863 \\
\text { 1. } 628\end{array}$ & $\begin{array}{l}74.0 \\
80.7 \\
92.4\end{array}$ & $\begin{array}{l}\text { 77. } 2 \\
67.9 \\
58.6\end{array}$ & $\begin{array}{l}\text { 2. } 054 \\
\text { 1. } 879 \\
\text { 1. } 628\end{array}$ & $\begin{array}{l}98.4 \\
94.7 \\
94.3\end{array}$ & $\begin{array}{r}0.190 \\
0.598 \\
-0.032\end{array}$ & $\begin{array}{l}0.858 \\
0.910 \\
0.997\end{array}$ & $\begin{array}{r}280.9 \\
205.2 \\
25.3\end{array}$ \\
\hline 2 & 39.5 & $\begin{array}{l}0.876 \\
0.959 \\
0.973\end{array}$ & $\begin{array}{l}\text { 1. } 991 \\
\text { 1. } 732 \\
1.693\end{array}$ & $\begin{array}{l}52.0 \\
59.8 \\
61.1\end{array}$ & $\begin{array}{l}70.5 \\
63.3 \\
63.0\end{array}$ & $\begin{array}{l}\text { 1. } 998 \\
\text { 1. } 761 \\
1.704\end{array}$ & $\begin{array}{l}92.4 \\
94.2 \\
96.7\end{array}$ & $\begin{array}{l}0.276 \\
1.082 \\
0.370\end{array}$ & $\begin{array}{l}0.874 \\
0.949 \\
0.969\end{array}$ & $\begin{array}{l}601.0 \\
515.2 \\
499.8\end{array}$ \\
\hline 3 & 36.7 & $\begin{array}{l}0.884 \\
0.980 \\
1.148\end{array}$ & $\begin{array}{l}\text { 1. } 964 \\
\text { 1. } 673 \\
\text { 1. } 282\end{array}$ & $\begin{array}{l}49.0 \\
57.5 \\
75.0\end{array}$ & $\begin{array}{l}59.2 \\
54.1 \\
41.5\end{array}$ & $\begin{array}{l}1.927 \\
1.690 \\
1.310\end{array}$ & $\begin{array}{l}80.5 \\
83.5 \\
84.9\end{array}$ & $\begin{array}{r}-1.185 \\
0.600 \\
1.278\end{array}$ & $\begin{array}{l}0.895 \\
0.974 \\
1.134\end{array}$ & $\begin{array}{l}440.6 \\
375.2 \\
125.4\end{array}$ \\
\hline 4 & 58.7 & $\begin{array}{l}0.799 \\
0.887 \\
0.996\end{array}$ & $\begin{array}{l}2.279 \\
\text { 1. } 954 \\
\text { 1. } 631\end{array}$ & $\begin{array}{l}67.5 \\
78.7 \\
94.3\end{array}$ & $\begin{array}{l}75.5 \\
68.4 \\
58.7\end{array}$ & $\begin{array}{l}2.164 \\
\text { 1. } 960 \\
1.631\end{array}$ & $\begin{array}{l}91.4 \\
91.4 \\
94.3\end{array}$ & $\begin{array}{r}-3.472 \\
0.271 \\
0.024\end{array}$ & $\begin{array}{l}0.828 \\
0.885 \\
0.996\end{array}$ & $\begin{array}{r}299.6 \\
190.6 \\
1.5\end{array}$ \\
\hline
\end{tabular}
える。いいかえるならば，図-5.4の装䀦によって試料を 加冉することは，乙れによって拭料の物理们性啠を変え てしまうことであり，pをパラメータとする代りに $e な$ どをパラメータとしてもさしつかえないわけである。

一厅, 浸透水量の增乩にともなう体䅡変化には膨張と

表-5.6 地すべり粘土の吸水膨張試験結果

$G_{s}=2.62, P \doteqdot 0, \quad$ 一吸水収縮を示す。 
収縮とが見られ，乙れは浸透水量 $Q$ の時閒的変化と同傾 向をたどっている。てれを単位時閐の膨張率 $\varepsilon=\Delta l / l(\Delta l$ は膨張量, $l$ は試料の高さ) の時間変化として示すと図 -5.6のようになり, その傾问は数式として

$$
\frac{d \varepsilon}{d t}= \pm a_{\imath} \exp \left(-b_{\imath} t\right)
$$

で表わすととができる。 $a_{i}, b_{\imath}$ は時間経過にともなって 不連続に変わる係数になるが, てれは式 (5.3) を $t$ に ついて微分したものと同じ形式の数式となる。式 (5.7) のマイナス符号は吸水収縮を意味する。

実験結果を考察すると次のととがいえると思う。

(1) 図-5.6および表-5.6によると膨張率の時閒的変化 の割合 $d \varepsilon / d t$ 之浸透量 $Q$ との間には此例的な関係はな い。簡単に考えると適当な含水比と間ゲキ比のとき, 最 あ膨張量 $\Delta l$ が大きいといった現象が見受けられる。乙 れは浸透による土粒子の転移が土粒子閒の接触状態に関 係するもの上考えられる。土粓子間には接触面扔よび容 器の側壁との間に摩擦力を含む力が作用しているが, 式 （5.7）を検討すると，土粒子の転移にあたっては，乙れ ら接触面間には弾性変形および粘性変形的な要素むはい っている模様であるが，てれは実験装置にも関係してい る。また図-5.6によると，試料全体の土粒子が同時に転 移するのでなく，いくつかのグループに分かれて転移す るととを示しているが，乙れは水の浸透機構にも関係す る。

（2）試料に加える圧力を大きくすると浸透量 $Q$ 之膨張 量 $\Delta l$ とは減少する。また $d \varepsilon / d t-t$ について見ると土粒 子転移について粘性変形的要素が少なくなる傾向があ る。乙れは間ゲキ比の減少とともに土粘子接触面に加わ る摩擦力が大きく転移你祭して弾性変形要素が大きくな るものと解される (間ゲキ水圧が作用しない場合)。一 方, ゆく詰めた試料については, 浸透量は大きいが膨 張に際しての $d \varepsilon / d t-t$ 曲線は式 (5.7) の形をとらない。 また, 吸水膨張が進行すると $d \varepsilon / d t-t$ はジグザグ曲線に なる。

（3） 単位時間の浸透量の時間的変化 $d Q / d t-t$ について は，今般の装置では充分な資料が得られなかったが， $d \varepsilon / d t-t$ 之同じ傾向を示すあのと考える。しかし，既述 のように $Q$ が大きい場合， $\Delta l$ がかならずしも大きい之 は限らない。浸透量 $Q$ は一般的に見て初期含水量 $Q_{c}$ が 小さいほど增加する傾向にあるが，今般使用した装置は 底部が開放されていないので, 水が浸透する際に空気を 排除しながら湿潤線が降下し, 飽和度, 閒ゲキ比の小さ い試料は間ゲキに閉じ込められた空気が水の浸透をさま たげ，逆にQは減少する現象す生じる。てのような現象 が，現地の地すべり面または粘土層面の中で実際に起り 得るかいなかについては疑点が多い。

吸水膨張試験の結果で重要なととは, 含水比, 飽和度
の大きい試料には相当の水圧を加えたり，後述するよう に乱してやらなければ，いくら加水しても吸水膨張は起 こらない。また地正 $p_{a}$ が大きいと吸水膨張をはなはだ しく困難にするなどの点であり，乙のことが地すべり粘 性土が賦存する付近の地中の状態によって，地すべり発 生とその後の動きに大きな影響を与えるところの closed water lens または closed water layerを 形成する原因 にあなっていることである。

\section{3 粘性土における粘着力と含水比との関係}

すべり面を観察すると部分的には直接セン断試験で見 る破壊面の状態に似ている。先に岩石の水浸テストにつ いて述べたが，ての岩不が地すべり粘土となったものを 採取し，てれに加水して練り返えしたものについて圧密 非排水試験を行ない, 粘着力 $C$ と初期含水比 $w$ との関 係を求めると図-5.1右下の直線のようになり

$$
C=A_{c} \exp \left(-B_{c} w\right)
$$

なる実験式が得られた。

ここに $A_{c}, B_{c}$ は係数である。一般に粘着力は $C=f\left(e_{0}\right.$, w）の関係があるといわれているが，今般実験に使用し た平山地すべり，元触地すべりなどの地すべり粘土につ いては式 (5.8)のような関数となる。

これら地すべり粘土について液性限界試験を行ない, 落下回数を $N$, 会水比を $w_{l}$ とすれば, 落下回数 $N$ を 刘数目盛にとった場合

$$
\log N=\log N_{0}+b \cdot w_{l} \text {. }
$$

で表わすととができるので式 (5.9) を書きかえると次の ようにあ表わすととができる。

$$
N=N_{0} \exp \left(-B_{l} \cdot w_{l}\right)
$$

いま, 半対数方眼紙の緃軸の対数目盛側に粘着力 $C$ お よび落下回数 $N$ をとり, 横軸に含水比 $w$ を算術目盛に とり, 式 (5.8) と式 (5.10)とをプロットすれば, 両直 線はほぼ平行となる。乙の関係を図-5.1の右下の実線之 右侧の破線によって示しているが

$$
B_{c} \fallingdotseq B_{l}
$$

が成立つようである。とてに， $B_{l}$ は液性限界における 流動指数 $I_{f}$ を特別の形式で表わしたものである。 以上の実験綕果を要約すると次のようになる。

(1) 式 (5.8) の関係は含水比が塑性限界之液性限界之 の間において近似的に成立する。すなわち，液性限界以 上の含水比では粘散力は矛策上零に近くなり, 塑性限界 以下の含水比では式 (5.8) の関係がいちじるしく乱れて

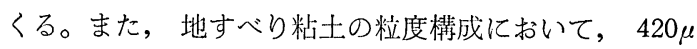
の通過百分率が $90 \%$ 以上の試料溚用される。

(2) 地すべり粘土の粘着力と含水比との関係を簡単に 知るには, 液性限界試験を行なって式 (5.10) の関係を 求め, $w_{L} \geqq w \geqq w_{p}$ の試料によって直接セン断試験を丰 施して $C$ を測定し, 四-5.1の形式に $C$ をプロットして, この点を通り式（․1C）で求式線に平行な直線を引 
けば大体の傾问を知ることができる。

（3） 今般使用した地すべり粘土は，流動指数が比較的 小さく䍀かな念水比の増师によって Cが急激に低下する 傾向が見られた。

(4) 式 (5.8) は粘着力 $C$ と含水比 $w$ との関係である が，粘禅力Cの時間的变化については，はっきりしたて とはわ汃らない。さきに示した図-5.4の四筒容器内にお ける試料の粘着力Cの時間的変化を推定するならば，式 (5.4) と式 (5.8) 加ら

$$
C=A_{c} \exp \left[-B_{c} \cdot Q_{s}\left(1-e^{-K t}\right)\right] \cdots
$$

の関係になるようである。こてでは試料の含水比が增加 した埸合，そのままの状態で粘着力Cの低下がおてると しているが，陌没曲線の測定などを総合すると，実際に
はかなり雌った形式になり

$$
C=A_{c} \exp \left[-B_{c} \cdot f(t)\right]
$$

になっているようである。

（涙完）

\section{参 考 文 献}

1）野时光雄：九州鉱山学会誌 Vol. 25, No. 11, p. 443 452

2）玉田文吾: 符 1 回土碩工学研究発表会詿演集

3）互田文吾：同上

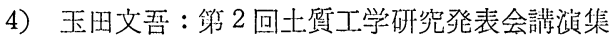

5）玉田文吾：第 1 回土質工学研觉発表会偝演集

6) 竹原平一: 九州鉱山学会誌 Vol. 24, No. 8 12

7）竹原平一：同上

\section{シンポシクムのお知らせ}

われわれ地すべり研究者が最近とくに気がつくのは，すべてが自然のままで発生する地すべりに 対し，切り取り，盛土，湛水，トンネルなど人工によるあのの比率が著しく增加したてとでありま す。自然改造といっても，大はダムの施工から，小は農道の掘削までいろいろあるが，その工事を 行なうととが，いかに地すべりに影響するか予測するととが非常に大切になってくる。その意味で 全国大学に籍を置く，地すべり研究に関心を持持ちになっている種々の尃門の先生方に参加して頂 いて 3 年間にわたって共同研究を行なう計画を立て文部省に申請しておったところ，採択の内示を 頂きました。予測の研究をあらゆる専門を通して行ないますが，年 2 回ずつダムの問題，道路・鉄 道の交通問題，宅地造成の問題と 3 つ実際問題に議題を分類してシンポジゥムを行ないたいと思 っております。

開催地は遂次札昽・仙台・東京・名古屋・広帠・福阔などで行なって地域的な特性をむ研究して 行きたいと思っております。シンポジゥム開催の日時，場所などにつきましては，そのつど誌上で 連絡いたしますので，地すべり学会々員の方々も畜って御参加くださいますようお願い致します。

御参若までに44年度の研究組織抒よび分担の先生方の御氏名を下浉にしるしました。

(氏 名)

田治米鏡二 (北 大・理)

岡 田 廣 (北大・教遥)

佐々 保雄 (北 大・理)

河上 屏義（東北大・工）

西田讋一（新 大・理）

䅦 村武(新大・理)

杉山 隆二（信 大・理）

藤井 昭二 (富 大・教育)

塚野善蔵（福 大・教青）

三浦静（福 大・教育）

贸川 克已 (福 大・教育)

“絈野䔐夫（金沃大・理）

松沢斯 (名大・理)
(氏 名)

駒村富士弥（三重大・農）

山口 真一 (京 大・防災研)

遠滕 隆一(京大・農)

武居 有恒 (京 大・農)

奥田 節夫（京 大・防災研）

高田 雄次（京 大・防災研）

村山 朔郎（京 大・防災研）

川端 博（京教大・ ）

正城 遀夫（大阪工大・）

川本整（大阪工大・）

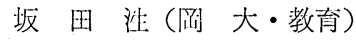

美骊忠夫（阔 大・工）

綱下 㭋夫 (広 大・工)
(氏 名)

岩崎 正夫 (徳 大・教育)

中川 衰三（徳 大・教育）

小田 英一（徳 大・工）

中村総七郎（愛媛大・農）

杤木 省二 (高知大・農)

岡崎 契彦 (高知大・農)

紃田壹 (高知大・農)

山崎 達雄（九大・经産科研）

西田 正（九大・生産科研）

内田一郎 (九 大・工)

德光 盖治 (九 大・工)

藤 本 廣 $($ 宫崎大・工） 